\title{
Development between problems, criticisms and possibilities: still a proposal under construction
}

\begin{abstract}
Summary
The aim of this article is to defend the validity of developmental and developmental proposals based on an endogenous bias, in opposition to the undifferentiated post development critique. In carrying out a literature review on theorists, the work recognizes the legitimacy of some evaluative analyzes from post development, admitting that the history of development enables severe criticism. But it is understood that such criticisms cannot be extended in an undifferentiated way to the recent alternative proposals of endogenous development that seek to distance themselves from the original propositions around the term.
\end{abstract}

Keywords: development, post development, endogenous, socioeconomic indicators, neoliberalism, discursive legitimation, economic growth, protagonism

\author{
Volume I Issue 2 - 2017
}

\author{
Maiara Tavares Sodré \\ Geography Postgraduate Program CNPq Scholarship, São Paulo \\ State University, Campus of President Prudente, Brazil
}

\begin{abstract}
Correspondence: Geography Postgraduate Program CNPq Scholarship, São Paulo State University, Campus of President Prudente, Brazil, , Email maiara.sodre@hotmail.com
\end{abstract}

Received: July 17, 2017 | Published: August 15, 2017

\section{Introduction}

The article that follows aims at the defense of alternative proposals of development, in opposition to the undifferentiated critique of post development. Thus, briefly the development history is resumed and alternative proposals of employment of the term are presented. Also, throughout the text, post developmental criticism is opposed, reserving the right to present a counter criticism.

\section{Development: the ghost of its own history}

The term development, in the sense in which it is currently added to refer to the condition of countries or regions, designates the process that leads to the improvement of the socioeconomic indicators of a given spatial delimitation. This conception of development was symbolically Cunhadano day on January 20, 1949, in the inaugural address of President Harry Truman. ${ }^{1}$ Since then, the term development, while maintaining little of the core of meaning mentioned above, has advocated different instruments for achieving progress. Similarly, the word development also incorporated different adjectives, which it is prudent to anticipate criticism did not always convey different content to accompany the new proposed vocabulary.

In 1949 the instrument of development, that is, of the South expansion of the developed condition of which the industrialized countries were already exploited, undressed underneath by Truman's discourse, consisted of Fordism and its classic model of expansion of corporations In developed countries to the world peripheries, with the possibility of maximizing the profits of these companies (via the use of favorable local conditions such as cheap labor and tax exemptions) and externalization of the environmental impacts generated in their productive processes. A model that lasted until the 1970s, when neoliberalism started to emerge, advocating a retraction in the social and regulatory role of the state over the economy. Here, the passport for the remission or amortization of the external debt of poor countries is granted through imperatives such as privatizing, easing labor legislation and facilitating the entry of foreign capital; A process whose conclusion Peet ${ }^{2}$ summarizes well: Finally, even the supposed result, economic growth, does not necessarily reduce poverty, especially when growth follows the neoliberal design. Instead he produces a replica of his native United States salary stagnation for most, and even more wealth for those who already have so much they do not know what to do with what they have ... except to buy political influence and Finance 'economic research' in conservative wing think tanks. In other words, in order to receive debt forgiveness, supplicating countries have to restructure their economies in a neoliberal way in order to reward foreign capital. But neoliberal economies generate poverty. I hate to spoil the party, but debt forgiveness in its present form, on IFIs tutelage, produces poverty while supposedly reducing it. Benevolence is benevolence. ${ }^{2}$

The same decade of the 1970s also marks the acknowledgment of the limitations in terms of producing social advances in the development models up to then, which, together with a growing environmental concern, leads to proposals for sustainable development. This, as Rodrigues $^{3}$ points out, is based on the slogans ${ }^{4}$ of promoting equality among all and preserving the common heritage of humanity for future occupants of the Earth, with the aim of proposing a socialization of responsibilities over Degradation of the planet. Although, as Rodrigues $^{3}$ emphasizes, not all of them impact the environmental dynamics or take ownership of the profits from the processes leading to the production of these impacts in the same proportion.

\section{Post development: the ideas}

Indeed, a very succinct resumption of some of the major instrumentalities and objectives implicit in the different development proposals presented over the last century does not favorably end the term and support the severe criticism emanating from the poststructuralist current that proclaims an era of post development. According to Radomsky, ${ }^{5}$ these authors compose an intellectual movement that does not present a complete cohesion or uniformity of thought with regard to its approach ${ }^{6-8}$ and the positions of its affiliates; There are, in fact, only occasional approximations. There is, however, a general agreement among the defenders of this current regarding the critique of the development models mentioned above: the need to overcome them.

One of the issues most attacked by post development is the tax character of development, which establishes the search for the Western model of society as the single path to progress, in a process that undermines the diversity and cultural and ecological singularities 
of local contexts. It is, in reality, a value system that intends the universalization of a particular and specific type of society, in order to guarantee a discursive legitimation for the imperative of economic growth. ${ }^{8}$

Shiva $^{8}$ goes even further by stating that: The tyranny and hierarchical privileges that are part of the development impulse are also part of the globalizing knowledge in which the paradigm of development is rooted and from which derives its logical argumentation and its legitimation. The power with which the dominant system of knowledge has subjugated all others makes it exclusive and undemocratic. The democratization of knowledge has become a crucial prerequisite for human liberation because the contemporary system of knowledge excludes the human by its very structure. A process of this kind of democratization would involve such a redefinition of knowledge that the local and diversified would come to be considered legitimate and seen as an indispensable knowledge because the concreteness is the reality. Globalization and universalization are mere abstractions that violate the concrete, and therefore the real. This shift from globalization to local knowledge is important for the project of human freedom because it liberates knowledge from dependence on established forms of thought, making it simultaneously more autonomous and more authentic. ${ }^{8}$

There will be an opportunity to explore the content of such inflexible and idealizing accusations of the place as this, but for the time being it is worth analyzing post developmental understandings more thoroughly. What can be done when considering the book The Development Dictionary: a guide to knowledge as power, a work that brings together authors aligned to this orientation. Already in the introduction of the work Wolfgang Sachs stresses that the last decades can be described as the era of development, but that this period has already reached its end and that we are before the moment of writing its obituary Escobar ${ }^{6}$ had already proposed the same. According to the author, development functioned as an encouraging mirage, an unattainable ideal that justified efforts and sacrifices (of the greater part of the population) of all order. But today the illuminated target that motivated the cross straits begins to fade. Sachs ${ }^{7}$ argues that the ideal of development did not produce the promised results, becoming an anachronistic project, the aspirations it aroused were already exhausted and the historical conditions that in 1949 caused the diffusion of its search disappeared in the present time. The mythological construction around the socioeconomic and technological evolution of the United States and other industrialized nations begins to collapse in the face of the environmental consequences arising from the achievement of this status of superiority and the unshakable hope that technology itself would remediate the environmental impacts to which its own Political use $^{9}$ had also led to openly being questioned. So that there is little to regret about the end of the development era, its success is that it would have been disturbing: I fall countries 'successfully' followed the industrial example, five or six planet should be needed to serve as mines and waste dumps. It is thus obvious that the 'advanced' societies are no model; rather they are most likely to be seen in the end as an aberration in the course of history. The arrow of progress is broken and the future has lost its brightness: it holds in store more threats than promises. How can one believe in development, if the sense of orientation has withered away? Suspicion grows that development was a misconceived enterprise from the beginning. Indeed, it is not the failure of development which has to he feared, but its success. What would a completely developed world look like? We don't know, but most certainly it would he both boring and fraught with danger.
For development cannot be separated from the idea that all people so the planet are moving along one single track towards some state of maturity, exemplified by the nations 'running in front'. In this view, Tuaregs, Zapotecosor Rajasthanis are not seen as living diverse and non comparable way so the man existence, but as somehow lacking in terms of what has been achieved by the advanced countries. Consequently, catching up was declared to be their historical task. From the start, development's hidden agenda was nothing else than the Westernization of the world. ${ }^{7}$ There are many arguments with which to agree on this line of positioning and many who seem at least unsuspecting, but before debating them it is necessary to take a last look at post development, Escobar (2007) can help in this endeavor. The author criticizes the exogenous character of the macro projects of development historically implemented in the poor countries, pointing out the dumping of the majority of the population of the decision making process. At the same time, it treats development as a discursive creation, a representation built on mechanisms of power. A rhetoric that would have turned a vision of reality and action that legitimizes the sometimes enthusiastic, sometimes conformed, acceptance of the 'price' of development. ${ }^{6}$

\section{Alternative development proposals}

Instead of development, post developmental authors among whom, it must be said, Escobar ${ }^{6}$ is, in fact, the most restrained and reasoned in his practical propositions. ${ }^{10,11}$ They resort to vague proposals which now point to the need to establish a society founded on more materially deprived bases, or to evoke the protagonism of social movements in the new era that unfolds, in a sermon that often falls in the romanticization of these groups. The fact is that, in spite of the post development propositional poverty, recent years have witnessed the emergence of a profusion of alternative development proposals that seek to counteract the history of the ideas and instruments of action already associated with that term.

One of the most widespread and consolidated, endogenous development, is based on a conceptual and operational discussion which, according to Dansero et al., ${ }^{12}$ recommends a bottom up conception of development according to Ellis F \& Biggs $\mathrm{S}^{13} \mathrm{~A}$ counterproposal to top down projects, since it advocates that the population define, in a participatory and negotiated process, its own priorities; The territorial character of the territory, as a spatial dimension provided with identity for the affected groups and providing operationality for the projects to be implemented; And the construction of public policies of multidimensional scope, that is, attentive to social, economic, environmental and cultural aspects.

It is a territorially constructed, emancipatory and authentic development. It is possible to recognize and adopt in an adapted manner successful strategies in other contexts, avoiding an idealization of the place and the knowledge derived from that sphere. As Massey ${ }^{14}$ and it is worth remembering the aforementioned inflexibility of Shiva $^{8}$ the place is not the positive opposite of the global. This is also if not essentially locally produced in certain places. London and Mali play very different roles on the international stage. Endogenous development has territorial roots, but it is not self absorbed, it resists taxation presets because it has learned from its own nebulous history. In the wake of a proposal for endogenous development that is not intended to be collected from it-self, there was an occasion when Sachs ${ }^{15}$ proposal for a development based on the principle of equity was defended. That is, on a positive discrimination, which treats unequally the unequal, privileging small farmers and enterprises 
to the detriment of farms and larger companies? Very close to Massey ${ }^{14}$ recommendation on the need for a policy of specificity and the understanding of Demo ${ }^{16} \&$ Sachs $^{15}$ understands that equity must extrapolate at the national level and defends a redefinition of the productive and consumer patterns of development Of Northern countries, as well as an effective transit of resources from the North to the South and the encouragement of fair trade practices. One has to compromise with this understanding, but it is possible to go beyond it. More than the idea of compensation for inequality forged in the past, we must recognize not only the (preterit) temporal extent of inequality but also its spatial (present) extent. Since inequality takes place today, now, it has not only been an isolated and extraordinary event in the distant past, it is a constituent of the normality imposed by global and locally unequal power geometry. ${ }^{17}$ And here we have a point of agreement with the post development, in effect, "it is not possible to protect one's own house against robbery by asking the thief to return a small part of the loot. To be protected, it is necessary to prevent the assault from occurring". ${ }^{8}$

\section{The extent of post developmental criticism and counter criticism}

It occurs that development alternatives (endogenous, territorial, local) are also targets of post development criticism. In these, the construction of a negotiated consensus as a condition for the definition of local priorities is treated as a sterilization of conflicts for capitalist planning, ${ }^{18}$ in a line of argument that tends to question the democratic principle more than the vices and asymmetries that limit its application. These dissimitations are, however, remembered when it comes to questioning the possibility of dialogue between Actors with different margins of action due to a disparity of bases in what concerns power geographies, ${ }^{19}$ since the emphasis on the equity of alternative development proposals is ignored or neglected. There is also the extension of the critique to the old propositions around the term development that the endogenous development itself criticizes harshly to the endogenous slopes of application of the word. And of course, the possible evocation that there are only small rectifications, departing from the heart of the problem, the exclusionary, segregatory and inequitable nature of the capitalist economic system. ${ }^{18}$ Thus, given the limitations of criticism, which attacks the rhetoric of development, ${ }^{6}$ but cannot overcome the discourse, since it does not present any alternative to the world of the commodity, preferring to hide itself in an absolute or essentially laconic skepticism in propositional terms. ${ }^{20}$

Development, it must be remembered, is only an entry, a word, a linguistic unit, its content or nucleus of meaning for the alternative proposals that employ it is the change for the better. ${ }^{2,15,21}$ A definition that may seem imprecise and really is, because what is intended is not to propose, discuss and test principles and criteria as open (but also as coherent) as possible, so that the definition of the content of the 'Change for the better' is deliberately reserved as a right and a task of the social agents themselves (subjects, protagonists), not a privilege of the analyst. ${ }^{21}$ A number of points are to be conceded in the post developmental arguments, since, as already pointed out, the historical and even some present proposals of development justify the accusation that these projects only provided a litany that served as a wrapper for tax favoring strategies of capital flows to already affluent countries. It is truly a development that imposes a single path, Westernization, and neglects the possibility of other paths. But it is necessary to make a decision when going further. First, because, as we have tried to make clear, this is not the proposal of the alternative conceptions of development presented. Second, there is the risk of incurring the error, in which post development explicitly slips, of amalgamating diversity and inequality into a miscellany, making it difficult to distinguish between what exactly one wants to preserve.

It is a postmodern impetus very well incorporated by post development, a passive condescension to inequality (named diversity), which Bauman's lucid self criticism, ${ }^{22}$ denounces: The news of human poverty and suffering now appears as colorful reports amid the many images of the various forms of life that people have chosen or are destined to take (by history, religion, culture). For a mentality taught to treat society as an unfinished project that it was up to the administrators to complete, poverty was an abomination; their life expectancy depended exclusively on administrative determination. For the mentality that repels global visions, distrustful of all social engineering projects, this poverty is only an element in the infinite variety of existence. Once again, as in pre modern times, convinced of the inscrutable and timeless wisdom of the divine order, we can live with daily visions of hunger, lack of a roof, lives without future and dignity, and at the same time live happily, enjoy the day and sleep quietly at night. ${ }^{22}$ In this process, what Peet $\mathrm{R} \&$ Hartwick $\mathrm{E}^{1}$ call a sense of urgency are lost and it is easy to forget that millions of people today live in extreme poverty. In a disproportionate and almost irrational relativization, ${ }^{9}$ is the very idea of poverty (would not be less materialistic forms of existence?) Put in check and the meaning of the term "better" in the proposal of change for the better happens be questioning. Peet $\mathrm{R} \&$ Hartwick $\mathrm{E}^{1}$ statement about anxiety in integrating into development projects of millions of people living today under subhuman conditions of existence is treated by post development as a volition conditioned by the seduction of a narrative, People were indoctrinated to want development. Faced with a questioning of this nature, which casts doubt on the authenticity of the desire to abandon inopia, penury and pauperism, Massey ${ }^{17}$ placement, a severe critique of unidirectional and undemocratic development, seems to be the best answer, since in Any culture or society "clean clean water is better than dirty water". ${ }^{17}$

Yes, there is a discourse about development, but the problem is not the discourse, nor is it Western knowledge or, as already pointed out, technology, the problem is the asymmetrical power relations that use those instruments. "Post structural analyses often forget, in practice, the agency behind discourse, or over generalize agency as 'modernity' or 'power.' There is an over emphasis on representation and the en framing of imaginaries at the expense of practicality and action". ${ }^{1}$ In line with the understanding of these authors, it is understood that development has already been and still is used with aims that detract from an equanimous proposal of a better life for all, but this does not mean that the search for positive transformations should be abandoned In favor of a contemplative indulgence of diversity / inequality. Development still has an immense unrealized potential for appropriation from those who need it most. If, however, the macroeconomic logic of the capitalist system is still used as an excuse for an ascetic paralysis and development projects are treated as punctual and insignificant expedients, it is necessary to anticipate the themes of the following section and especially to highlight the last words of Ploeg et al. ${ }^{23}$ The Government Food Procurement Programme (PAA) and the National School Meal Programme (PNAE) are the best examples here of the active construction of new, nested markets showing how goal oriented cooperation between rural movements, farmers and state apparatuses can produce considerable synergy. To reduce transaction costs, PAA only buys food from associations of 
farmers. In 2009 PAA had a budget of 340 million US \$. In 2010 this was doubled. Compared to the total trade in agricultural and food products this might (again) appear as a tiny contribution. However, the PAA has created the nested market that sustains school meals (an essential element in the fight against hunger), whilst simultaneously constructing a market outlet for more than 300,000 poor and small scale farmers. Sometimes it is the details that are important. ${ }^{23}$

A brief and panoramic report was sufficient and sufficient to show that in the past, and possibly in many proposals today, there is no intention of changing the lives of people in an equitable way. There are alternative propositions, however. These are dissonant ideas of those obducted in the words of Truman and find in a multidimensional perspective, which recognizes and seeks to combat the disparities of power, its core. Do not try even believe it readymade recipes, able to idyllically solve all the problems of the context to which they are concentrated. ${ }^{24-26}$ They seek to identify their limitations, learn from them and overcome them, or at least mitigate them. They do not deny the contradictions of origin of the system, but do not use them as a subterfuge for impassibility, for the preconceptions of esoteric faculties, and see disparities as the different, the absence of material conditions of existence as idiosyncrasies. In this way, autonomous development projects are designed, capable of making criticism including those of post development a point of reflection for its own improvement or eventual reformulation. Yes, the endogenous or territorial development looks forward because it is also able to look back and not forget about its meritorious past. In the same way, he looks sideways without embarrassment, as he does not hesitate to identify and admit the existence of other successful initiatives beyond his own territory, being always unobstructed to adopt such policies in an adapted and conditioned way to the democratic examination of the local actors. There is no way to erase the indelible history of development, and indeed it is helpful to do so. A nuvial past provides a watchful gift and allows for an open future, both in terms of its theoretical plan and its operational and concrete possibilities.

\section{Acknowledgements}

None.

\section{Conflict of interest}

The author declares no conflict of interest.

\section{References}

I. Peet R, Hartwick E. Theories of development: contentions, arguments, alternatives. 2nd ed. USA:The Guil Ford Press; 2009. 324 p.

2. Peet R. Imaginaries of development. In: Fernandes BM, et al. editors. Agrarian geography: theory and power. Popular Expression, Brazil; 2007. p. 19-37.

3. Rodrigues AM. Sustainable development: from class conflicts to conflict of generations. In: Silva JB, et al. editors. Panorama of the Brazilian geography II. Brazil:Annablume; 2006. p. I0I-II3.

4. Leff E. Political Ecology: a Latin American perspective. Development and Environment. 2015;35(3):29-64.

5. Radomsky GFW. Development, post-structuralism and postdevelopment: the critique of modernity and the emergence of alternative “modernities”. Brazilian Journal of Social Sciences. 20 I I;26(75): 149-162.

6. Escobar A. The invention of the Third World: construction and development of development. Editorial Foundation the dog and larana.Venezuela; 2007.
7. Sachs W. The Development Dictionary: A Guide to Knowledge as Power. 2nd ed. UK: Zed Books; 2010.353 p.

8. Shiva V. Monocultures of the mind: perspectives on biodiversity and biotechnology. UK: Creative Commons License, Zed Books; 2003.

9. Sokal A, Bricmont J. Intellectual Impostures: The Abuse of Science by Postmodern Philosophers. 4th ed. Brazil; 2010.

10. Guzmán ES, Woodgate G. Agroecology: Foundations in Agrarian Social Thought and Sociological Theory. Agroecology and Sustaining Food Systems. 20I3;37(I):32-44.

I I. Radomsky GFW. Reciprocity, social networks and rural development. In: Schneider S, editor. The diversity of family farming. 2 nd ed. Editora UFRGS, Brazil; 201 I. p. 107-136.

12. Dansero E, Giaccaria P, Governa F. Local development: confronting national contexts. In: Saquet MA, Sposito ES, editors. Territories and territorialities: theories, processes and conflicts. Brazil; 2009. p. 249-269.

13. Ellis F, Biggs S. Envolving Themes in Rural Development 1950s-2000s. Development Policy Review. 200 I; 19(4):437-448.

I4. Massey D. For space: a new policy of spatiality. Brazil; 2008.

I5. Sachs I. Development: inclusive, sustainable, sustained. Garamond, Brazil; 2008.

16. Demo P. Holy State, damn market: certain lefts that are right. Society and State. $2005 ; 20(2): 451-476$.

17. Massey D.The conceptualization of space and the question of politics in a globalized world. In: Silva JB, Lima LC, editors. Panorama of the Brazilian geography I. Brazil:Annablume; 2006. p. I I-19.

18. Montenegro Gómez JR. Development in construction: provocations and questions about development and geography. In: Fernandes BM, et al. editors. Agrarian Geography: theory and power. Popular Expression, Brazil; 2007. p. 39-54.

19. Montenegro Gómez JR. The limits of consensus - the proposal for rural territorial development in Latin America. In: Fernandes BM, editor. Peasantry and agribusiness in Latin America: the current agrarian question. Popular Expression, Brazil; 2008. p. 249-274.

20. Moraes ACR. On the trail of purgatory: politics and modernity in contemporary Brazilian geography. In: Silva JB, et al. editors. Panorama of the Brazilian geography II. Brazil:Annablume; 2006. p. 39-46.

2I. Souza ML. The fundamental concepts of socio-spatial research. Bertrand Brasil, Brazil; 2013.

22. Bauman Z. Modernity and ambivalence. Brazil: Jorge Zahar; 1999.

23. Ploeg JDV, Jingzhong Y, Schneider S. Rural development through the construction of new, nested, markets: comparative perspectives from China, Brazil and the European Union. Journal of Peasant Studies. 2012;39(I):133-173.

24. Alves, AF, Guivant JS. What is there other than the endogenous and exogenous in research on rural development? In: Saquet MA, Santos RA, editors. Agrarian Geography, territory and development. Popular Expression, Brazil; 2010. p. 89-106.

25. Schejtman A, Berdegué J. Rural territorial development. Chile: Working Paper, RIMISP; 2003. $71 \mathrm{p}$

26. Sodré MT. Public policies for the family agrarian system and the interfaces with rural territorial development: a study on the repercussions of the PAA and PNAE in the municipality of Pelotas / RS.2 I 6f. 2016. Brazil: Dissertation (Master in Geography)-Federal University of Rio Grande; 2016. 